Open Access

\title{
Susceptibility of New Zealand flora to Phytophthora kernoviae and its seasonal variability in the field
}

\author{
Judy Frances Gardner ${ }^{* \dagger}$, Margaret Anne Dick ${ }^{\dagger}$ and Martin Karl-Friedrich Bader
}

\begin{abstract}
Background: The oomycete Phytophthora kernoviae is known from the United Kingdom and the Republic of Ireland, where it is considered to be a recent invader, from Chile where it was only discovered in 2014, and New Zealand where records date back to 1953. As there is little information in New Zealand linking P. kernoviae with plant disease, it may have been present for much longer and may be indigenous. Seasonal activity of $P$. kernoviae in a site known to have infested soil was tested by isolation from soil and foliage of existing shrubs and the use of indicator plants. In greenhouse studies, the susceptibility of a range of indigenous plants to $P$. kernoviae was tested via stem and foliar inoculation.

Methods: Soil, litter and understorey vegetation samples were collected for isolation of $P$. kernoviae at monthly intervals for a year. Plants of Rhododendron catawbiense, which is known to be susceptible to foliar and shoot infection, were placed in the stand as indicator species. In laboratory and greenhouse studies, stem and foliar inoculations of a selection of arborescent plants representing major groups within the New Zealand flora were carried out and compared with three exotic plants of known susceptibility.
\end{abstract}

Results: Phytophthora kernoviae was not isolated from foliage of understorey plants at the study site, but it was recovered from soil and litter from April to November (autumn through spring) inclusive. Little disease developed on the Rhododendron catawbiense indicator plants.

All of the exotic, and most of the indigenous, species developed a lesion in response to stem inoculation. Stem lesions were more developed on exotic species than on indigenous hosts. In contrast, few species formed foliar symptoms. Phytophthora kernoviae was recovered from asymptomatic tissue, stems and foliage, of a number of species.

Conclusions: Based on the results of the inoculations and the lack of historical records of disease of indigenous plants associated with $P$. kernoviae, this oomycete does not appear to be a damaging pathogen of New Zealand's indigenous flora. Although presence in the soil or litter was demonstrated at the study site, little disease developed on the indicator plants suggesting that at least part of the New Zealand population is of low pathogenicity to R. catawbiense.

Keywords: Phytophthora kernoviae; Plant disease; Forestry; New Zealand flora; Susceptibility

\footnotetext{
* Correspondence: judy.gardner@scionresearch.com

${ }^{\dagger}$ Equal contributors

New Zealand Forest Research Institute (Scion), Private Bag 3020, Rotorua

3046, New Zealand
}

\section{黑 Springer}

(c) 2015 Gardner et al. Open Access This article is distributed under the terms of the Creative Commons Attribution 4.0 International License (http://creativecommons.org/licenses/by/4.0/), which permits unrestricted use, distribution, and reproduction in any medium, provided you give appropriate credit to the original author(s) and the source, provide a link to the Creative Commons license, and indicate if changes were made. 


\section{Background}

Phytophthora kernoviae Brasier, Beales and S.A. Kirk is an oomycete pathogen that infects a range of plant genera (Brasier et al. 2005; Beales et al. 2006; Beales et al. 2009) in the United Kingdom and the Republic of Ireland causing foliar necrosis and shoot dieback on both tree and shrub hosts, and bleeding cankers on some tree hosts. Response to infection ranges from host mortality to minor foliage spotting depending on the host species affected (Denman et al. 2006b). Inoculum in the form of sporangia and zoospores is produced on infected foliage but generally not on bleeding cankers of the trees which are thereby designated "dead-end hosts" (e.g. Davidson et al. 2005). Denman et al. (2009b) also demonstrated that $P$. kernoviae could infect the foliage of some plants without symptom expression.

More recently, P. kernoviae has been found to naturally infect plants from 20 genera representing 13 families (Anon 2012; Dick et al. 2014) in New Zealand and other parts of the world. Host plants are predominately angiosperms although three conifers, each from a different family, are also recorded hosts (Anon 2012; Dick et al. 2014). Additional host species have been shown to be susceptible with artificial inoculations (Anon 2012, Fichtner et al. 2012).

The existence of P. kernoviae in New Zealand was first recognised early in 2006 (Ramsfield et al. 2009) although it had been recorded earlier as an undescribed species (McAlonan 1970). In 2006, it was known as a pathogen only of the introduced cherimoya (Annona cherimola Mill.) from orchards in the far north of the country (Ramsfield et al. 2009). Other isolates, which were from Northland and the Central Plateau of the North Island, were from soil and were not linked to plant disease. However, P. kernoviae has now been recovered from locations throughout the North Island, and from a few locations in the Westland and Nelson regions in the South Island of New Zealand (MA Dick, unpublished data). In addition to infecting $A n$. cherimola, foliar necrosis of Rhododendron spp. and Pinus radiata D.Don (both exotics) has occasionally been recorded (Dick et al. 2014). To date, Phytophthora kernoviae has been isolated only twice from native New Zealand species, once from the dying lower foliage of a podocarp Prumnopitys ferruginea (D.Don) de Laub (Dick et al. 2014) and once from an asymptomatic fern Blechnum novae-zelandiae T.C. Chambers and P.A. Farrant (MA Dick, unpublished data).

Little is known of the life cycle and ecology of Phytophthora kernoviae in New Zealand. Apart from the disease outbreak on An. cherimola, there is no evidence of the destructive behaviour that has been reported in woodlands and heathlands in parts of Great Britain (Brasier et al. 2005; Beales et al. 2006, 2009; Denman et al. 2006a, 2009). Phylogenetically, P. kernoviae is located in Phytophthora clade
10 and hence has a likely Southern Hemisphere connection (Ramsfield et al. 2009). The recent identification of P. kernoviae from indigenous forest in Chile (Sanfuentes et al. 2014) may lend further support to this concept. The hypothesis that P. kernoviae is native to New Zealand is being tested using a population genetic study (D. Cooke, D. Studholme and R. McDougal, unpublished data). If this hypothesis is found to hold true, then P. kernoviae may be either acting as an occasional minor pathogen of indigenous plants or it could be endophytic and generally having no detrimental effect on its hosts.

This paper reports on several studies undertaken to develop an understanding of the life cycle of P. kernoviae in New Zealand and to determine the effect that it has on New Zealand indigenous plants. Firstly, the recovery of $P$. kernoviae from soil and litter throughout the year was examined at a forest location where this species had been recorded in the 1950s and 1960s (McAlonan 1970) and subsequently in 2006 (M. Bullians, unpublished data). Secondly, understorey vegetation (both exotic and indigenous plants) was evaluated and foliage with lesions of unknown cause collected for analysis each month for 8 months from September 2007 until April 2008. Plants of $R$. catawbiense Michx., which is known to be susceptible to P. kernoviae (Denman et al. 2005), were taken into one stand as indicator plants for P. kernoviae pathogenic activity.

In addition, glasshouse and laboratory studies included stem and foliar inoculations of a selection of arborescent plants representing major groups within the New Zealand flora, and on a number of ferns that are common in plantation forest environments. The ability of P. kernoviae to colonise these tissues asymptomatically after inoculation was tested through re-isolation. Lesion formation was also recorded. For comparison, three exotic host species of known susceptibility were also inoculated.

\section{Methods}

Field study

\section{Site}

Four plots (labelled 'a'-'d'), each $1.5 \mathrm{~m}^{2}$, were established about $250 \mathrm{~m}$ apart within a plantation of 20-year-old Pinus radiata where soil had tested positive for Phytophthora kernoviae in 2006. The plantation was located at Pinedale $\left(38^{\circ} 03^{\prime} \mathrm{S}, 175^{\circ} 48^{\prime} \mathrm{E}\right)$ in the central North Island.

\section{Indicator plants}

Rhododendron catawbiense plants were used both as indicator plants for P. kernoviae pathogenic activity and to provide bait leaves for soil bioassays.

A 1-m-tall $R$. catawbiense was planted in August 2007 at each of plots 'a' and 'b'. These plants were monitored monthly for any typical symptom development. Three leaves were collected each month from 
each plant, symptomatic leaves if present or healthy leaves if there were no signs of disease, for isolation in the laboratory. If dieback occurred, branch or twig samples were collected for isolation from affected tissue. Once dead, these plants were dug up and returned to the laboratory for analysis.

A potted 50-cm-tall $R$. catawbiense was placed at each of plots 'a' and 'b' in each month from October 2007 to April 2008. Each month, the previous month's plants were collected, placed in a shade house at the laboratory and monitored for development of leaf lesions and dieback. Plants were spatially separated and bottom-watered to ensure that no cross-infection could occur. Any diseased material was collected for isolation in the laboratory. Plants used for this trial were propagated by cuttings from a parent plant to ensure genetic uniformity.

\section{Soil samples}

For each of the four plots, soil and plant litter were collected with a trowel from three randomly selected places within the plot to a soil depth of $150 \mathrm{~mm}$. The three samples from each plot were bulked and thoroughly mixed. The total amount of soil and litter was not less than $1.0 \mathrm{~L}$ per plot. Samples were collected at monthly intervals and analysed in the laboratory as described below. Soil sampling commenced in April 2007 and was carried out for 12 months.

\section{Understorey plants}

Foliage samples from the six understorey plants that dominated the plots and the immediate area surrounding the plots were collected each month from July 2007 until April 2008. These species were: Bl. novae-zelandiae (palm-leaf fern); Cyathea medullaris (G.Forst.) Sw. (tree fern), two ground ferns (Pteris tremula R.Br. and Diplazium australe (R.Br.) N.A. Wakef.), Rubus fruticosus agg. (blackberry) and Metrosideros diffusa (G.Forst.) Sm.) (climbing rata). Foliage with lesions of unknown cause was selected, but healthy leaves were also included. Leaves from a sole Camellia sp. bush (probably originating from garden rubbish that had been dumped near plot ' $a$ ') was also sampled as Camellia species are a recognised host of Phytophthora kernoviae in the United Kingdom. The samples were tested for Phytophthora kernoviae in the laboratory.

\section{Isolations}

Soil samples Each soil sample was flooded with distilled water to a depth of twice the depth of the soil and four $R$. catawbiense leaves floated on the surface of the water as bait. After 7 days, bait leaves were surface sterilised, cut into sections and plated onto amended synthetic Mucor agar (SMA) medium (prepared as described by
Brasier et al. 2005) and incubated in the dark at $20{ }^{\circ} \mathrm{C}$ for up to 14 days. Any Phytophthora-like colonies were sub-cultured as they emerged onto carrot agar (CA) (Erwin and Robeiro 1996) for identification. Colony morphology, sporangial and gametangial characters were examined, and the temperature at which mycelial growth ceased was determined. DNA sequencing of selected isolates was carried out to confirm morphological identification of P. kernoviae.

\section{Leaf samples}

Small pieces $\left(5 \mathrm{~mm}^{2}\right)$ of leaf were cut either from live/ dead margins of lesions if present or from random pieces from healthy leaves. Leaf pieces were surface sterilised and placed on SMA or pimaricin, ampicillin, rifampicin and pentachloronitrobenzene (PARP; Jeffers and Martin 1986) media and incubated in the dark at $20{ }^{\circ} \mathrm{C}$. Phytophthora-like colonies were examined as described for those obtained from soil samples.

\section{Inoculations \\ Species selection}

Eighteen native plant species for stem inoculations and 29 native species for foliar inoculations were selected from 17 genera. Species choice was influenced by availability of potted plants for the stem inoculations. Both canopy and understorey plants from the major forest types (broadleaf-podocarp and beech) were represented. Three exotic species (Fagus sylvatica L., An. cherimola and $R$. catawbiense) were also inoculated for comparison as these are known susceptible hosts of P. kernoviae. All host species are listed in Table 1 . The plants were potted and were held in a shade house during inoculation and for the assessment period of 3 months.

\section{Phytophthora kernoviae isolates}

Four isolates of P. kernoviae (NZFS 2646, NZFS 3062, NZFS 3339 and NZFS 2707) obtained from the New Zealand Forest Research Institute Culture Collection were used for the inoculations. Details of the original host and collection date are provided in Table 2. All isolates were grown on $\mathrm{CA}$ medium at $18{ }^{\circ} \mathrm{C}$ in the dark for 14 days prior to use.

\section{Stem inoculations}

Two isolates (NZFS 2646 and NZFS 3062) were used for stem inoculations. Inoculum comprised a 5-mm-diameter mycelial plug taken from the edge of an actively growing colony. Carrot agar plugs without cultures were used as controls.

A flap of bark (10 mm long $\times 3 \mathrm{~mm}$ wide) was peeled back from a clear section of the stem, midway between the soil level and first branch of the host plant, and the inoculum placed with the mycelium-side against the 
Table 1 Host plants used for stem and foliar inoculations with Phytophthora kernoviae isolates and number of replicates

\begin{tabular}{|c|c|c|c|c|c|c|c|c|c|c|c|}
\hline \multirow[t]{2}{*}{ Host } & \multirow[t]{2}{*}{ Family } & \multicolumn{3}{|c|}{ Stem inoculations } & \multicolumn{4}{|c|}{ Foliar inoculations } & \multicolumn{3}{|c|}{ Foliar inoculations of wounded leaves } \\
\hline & & $\begin{array}{l}\text { Isolate } \\
2646\end{array}$ & $\begin{array}{l}\text { Isolate } \\
3062\end{array}$ & Control & $\begin{array}{l}\text { Isolate } \\
2646 \\
\text { (b) }\end{array}$ & $\begin{array}{l}\text { Isolate } \\
2707 \\
\text { (a) }\end{array}$ & $\begin{array}{l}\text { Isolate } \\
3339 \\
\text { (d) }\end{array}$ & Control & $\begin{array}{l}\text { Isolate } \\
3339 \\
\text { wounded }\end{array}$ & $\begin{array}{l}\text { Isolate } 3339 \\
\text { Unwounded } \\
\text { inoculated } \\
\text { control }\end{array}$ & $\begin{array}{l}\text { Wounded } \\
\text { Control }\end{array}$ \\
\hline
\end{tabular}

\section{Ferns}

Blechnum novae-

Blechnaceae

zelandiae

T.C.Chambers and

P.A.Farrant

Cyathea medullaris

(G.Forst.) Sw.

Paesia scaberula (A.Rich.) Kuhn

Asplenium

bulbiferum G.Forst.

Pteris tremula R.Br.

Conifers

Agathis australis

(D.Don) Lindl.

Dacrycarpus

dacrydioides

(A.Rich.) de Laub.

Podocarpus totara

G.Benn. ex D.Don

Angiosperms-

monocotyledons

Cordyline australis (G.Forst.) Endl.

Angiospermsdicotyledons

Annona cherimola Mill. ${ }^{a}$

Beilschmiedia tawa (A.Cunn.) Benth.

and Hook.f. ex Kirk

Clianthus maximus

Colenso

Coprosma sp.

Corynocarpus

laevigatus J.R.Forst

and G.Forst.

Dodonaea viscosa

Jaca.

Fagus sylvatica $\mathrm{L}^{\mathrm{a}}$

Fuchsia excorticata

(J.R.Forst. and

G.Forst.) L.f.

Gaultheria depressa Ericaceae

Hook.f.

Griselinia littoralis

Raoul

Laurelia novae-

zelandiae A.Cunn.

Cyatheaceae

Pteridaceae

Annonaceae

Lauraceae

Fabaceae

Rubiaceae

Sapindaceae

Fagaceae

Onagraceae
Dennstaedtiaceae

Dryopteridaceae

Araucariaceae

Podocarpaceae

Podocarpaceae

$5 \quad 5$

5

5

Asparagaceae

Corynocarpaceae

544

10

3

$5 \quad 5 \quad 5$

18

31

5

5

5

5

5
Griseliniaceae

Atherospermataceae 5 
Table 1 Host plants used for stem and foliar inoculations with Phytophthora kernoviae isolates and number of replicates (Continued)

\begin{tabular}{|c|c|c|c|c|c|c|c|c|c|c|c|}
\hline $\begin{array}{l}\text { Leptospermum } \\
\text { scoparium J.R.Forst. } \\
\text { and G.Forst. }\end{array}$ & Myrtaceae & 5 & 5 & 5 & - & - & 15 & 5 & - & - & - \\
\hline $\begin{array}{l}\text { Lophomyrtus } \\
\text { bullata Burret }\end{array}$ & Myrtaceae & - & - & - & - & 19 & 10 & 5 & 10 & 10 & 10 \\
\hline $\begin{array}{l}\text { Melicytus ramiflorus } \\
\text { J.R.Forst. and } \\
\text { G.Forst. }\end{array}$ & Violaceae & 5 & 5 & 5 & 5 & 15 & 15 & 5 & - & - & - \\
\hline $\begin{array}{l}\text { Metrosideros excelsa } \\
\text { Sol. ex Gaertn. }\end{array}$ & Myrtaceae & 5 & 5 & 5 & 4 & 20 & 10 & 5 & 5 & 5 & 5 \\
\hline $\begin{array}{l}\text { Myrsine australis } \\
\text { (A.Rich.) Allan }\end{array}$ & Primulaceae & 5 & 5 & 5 & 5 & - & - & 5 & - & - & - \\
\hline $\begin{array}{l}\text { Nothofagus } \\
\text { menziesii (Hook.f.) } \\
\text { Oerst. }\end{array}$ & Nothofagaceae & 5 & 5 & 5 & 5 & 15 & 14 & 5 & - & - & - \\
\hline $\begin{array}{l}\text { Nothofagus } \\
\text { truncata (Colenso) } \\
\text { Cockayne }\end{array}$ & Nothofagaceae & 5 & 5 & 5 & 5 & 5 & 12 & 5 & - & - & - \\
\hline $\begin{array}{l}\text { Pittosporum } \\
\text { eugenioides A.Cunn. }\end{array}$ & Pittosporaceae & 5 & 5 & 5 & 5 & 11 & 5 & 5 & - & - & - \\
\hline $\begin{array}{l}\text { Pittosporum ralphii } \\
\text { Kirk }\end{array}$ & Pittosporaceae & 5 & 5 & 5 & 5 & - & - & 5 & - & - & - \\
\hline Pseudopanax sp. & Araliaceae & - & - & - & - & - & 10 & 5 & - & - & - \\
\hline $\begin{array}{l}\text { Pseudowintera } \\
\text { colorata (Raoul) } \\
\text { Dandy }\end{array}$ & Winteraceae & 5 & 5 & 5 & 5 & 20 & 5 & 5 & 5 & 5 & 5 \\
\hline $\begin{array}{l}\text { Rhododendron } \\
\text { catawbiense } \\
\text { Michx. }\end{array}$ & Ericaceae & - & 4 & 3 & - & 18 & - & 5 & 5 & 5 & 5 \\
\hline
\end{tabular}

${ }^{\mathrm{a}}$ Species not native to New Zealand

sapwood. The flap was placed back in position over the inoculum, the wound wrapped in moist cotton wool, then with plastic sealing film (Parafilm $\mathrm{M}^{\ominus}$ ) and then covered with aluminium foil. The number of replicates for each host species inoculated with each of the isolates and the controls is shown in Table 1.

After inoculation, plants were placed in a randomised block arrangement within the shade house. Where possible, each of the five blocks consisted of one plant of each species with a stem inoculation of each isolate and one control inoculation for each species. Plants were watered from below as required to maintain moist soil. Inoculations took place in the spring with night time temperatures ranging from 1 to $19{ }^{\circ} \mathrm{C}$ with means of 9,10 and $12{ }^{\circ} \mathrm{C}$ for the months of September, October and November, respectively. Day time temperatures were marginally higher, ranging from 2 to $24{ }^{\circ} \mathrm{C}$ and means of 12,13 and $16{ }^{\circ} \mathrm{C}$ for the 3 months as above.

Plants were examined weekly, and any wilting or other indications of decline were recorded. All of the plants were destructively sampled 3 months after inoculation. Bark was peeled back from the wound and lesions or discolouration in the wood measured. Isolations were made from the centre, from $10 \mathrm{~mm}$ above and from $10 \mathrm{~mm}$ below the centre of the wound. For those plants with lesions or discolouration of the sapwood beyond the inoculation wound, isolations were also made from all the margins of the discoloured tissue. Pieces of wood (approximately $4 \mathrm{~mm}^{3}$ ) were excised from the host and were plated onto PARP. After 5 and 10 days, any Phytophthora-like colonies that had formed were transferred to

Table 2 Isolates of Phytophthora kernoviae used for inoculations

\begin{tabular}{|c|c|c|c|c|}
\hline NZFS & ICMP & Host & Geographical region & Date collected \\
\hline 2646 & 16306 & Annona cherimola & Northland & 19 November 2005 \\
\hline 2707 & & Blechnum novae-zelandiae & Waikato & 27 July 2006 \\
\hline 3062 & & Rhododendron catawbiense & Waikato & 18 December 2007 \\
\hline 3339 & & Rhododendron sp. & Wellington & 21 December 2009 \\
\hline
\end{tabular}


CA for identification using the method described in the soil sampling.

\section{Foliar inoculations}

Segments of agar from the actively growing margin of 7day-old cultures of NZFS 2646, NZFS 2707 and NZFS 3339 (Table 2) were placed in sterile pond water and held at $20{ }^{\circ} \mathrm{C}$ with a $12 / 12$-h light/dark cycle for $72 \mathrm{~h}$ to induce sporangial production. Zoospore release was promoted by placing the solutions at $4-6{ }^{\circ} \mathrm{C}$ for $20-60 \mathrm{~min}$ and then returning to $20{ }^{\circ} \mathrm{C}$. Zoospore concentration was determined using a haemocytometer. Zoospore concentration ranged from $1.0 \times 10^{4}$ to $6.0 \times 10^{4}$ zoospores $/ \mathrm{mL}$. The number of replicates, for each host species, inoculated with each isolate and the controls is shown in Table 1.

Foliage inoculation 1 Leaves of 32 host species (Table 1) were inoculated on the day they were collected. Detached leaves were dipped (apical end) into a freshly prepared zoospore suspension and held there for $5 \mathrm{~min}$. For host species with small leaves (e.g. Leptospermum scoparium), the apical end of a small branch with leaves attached was dipped in the inoculum. Replicates ranged from three to 30 . Five or ten leaves of each species were dipped into sterile pond water as control treatments. The dipped material was then laid on moist paper towels in containers and covered in plastic wrap held in a culture cabinet at $20{ }^{\circ} \mathrm{C}$ with a $16 / 8$-h light/dark schedule. Lighting was provided by cool white fluorescent tubes.

Foliage inoculation 2 Leaves of 10 host species, three exotic and seven indigenous (Table 1) were wounded by cutting off the apical end prior to dipping in a spore suspension of NZFS $3339\left(2 \times 10^{4}\right.$ zoospores $\left./ \mathrm{mL}\right)$. Equal numbers of non-wounded leaves were dipped concurrently. The inoculation and monitoring procedure was as described above for inoculation 1. There were five replicates each of wounded and non-wounded leaves with the exception of the small-leaved Podocarpus totara (20 replicates) and Lophomyrtus bullata (10 replicates).

Leaves were monitored every 2 days for lesion development. After 7 days, all leaves (whether symptomatic or not) were surface sterilised in $70 \%$ ethanol for $30 \mathrm{~s}$, rinsed in sterile distilled water and plated onto PARP. Plates were incubated at $18{ }^{\circ} \mathrm{C}$ in the dark. Phytophthora-like colonies were transferred to $\mathrm{CA}$ for further examination and identification as for soil sampling.

\section{Statistical analysis}

All statistical computations were performed within the $\mathrm{R}$ software environment (R Core Team 2014). Generalised linear models using a binomial distribution and logit link were used to analyse the stem and foliar pathogen recovery data, which were recorded as binary responses. The occurrence of quasi-complete separation resulting from the null response seen in numerous species required the use of the Firth-bias reduction (Kosmidis 2013). The response variable was represented by a two-column matrix holding the number of 'successes' (positive recovery) and 'failures' (no recovery). Species identity was modelled as the sole explanatory variable. The large number of tested species (>20), made multiple comparisons ineffectual and, therefore, the responses of the native taxa were pooled and compared with the lumped response of the exotic species. The data aggregation involved with this approach resulted in proportions, which were modelled using generalised additive models for location scale and shape (Rigby and Stasinopoulos 2005).

Stem lesion length was modelled using generalised least-squares models fitted by restricted maximum likelihood (Pinheiro et al. 2014). As described above, species identity and later the pooled responses of native vs. exotic species were modelled as the sole explanatory variable. Graphical validation tools were used to check the model assumptions (residual plots for variance homogeneity and quantile-quantile plots for normality). Heteroscedasticity was detected and modelled with an exponential variance structure using the fitted values as variance covariate.

For all models, the significance of the main effect was tested using likelihood ratio tests.

\section{Results \\ Field study \\ Indicator plants}

Plot A The planted rhododendron remained healthy from August to February but subsequently wilted and died. Phytophthora kernoviae was not recovered from the three healthy leaves collected each month nor from any part of the dying plant, including the roots, at any time.

Potted rhododendrons did not exhibit leaf or shoot dieback, and P. kernoviae was not recovered from any asymptomatic foliage that was tested.

Plot B Some shoots on the planted rhododendron died back after 3 months (in December), and the plant continued to decline thereafter. Phytophthora kernoviae was isolated from the margins of dead shoot tissue in December and February. The three leaves collected each month tested positive for P. kernoviae in September and December although only the December leaves had lesions. The plant was dead by the end of March. No $P$. 
kernoviae was isolated from roots (including fine roots) when the plant was uprooted and dissected.

Necrosis was present on the potted rhododendrons exposed during October, November, December, February and March, and P. kernoviae was recovered from the leaves in November, December, February and March. No further symptoms developed on the plants once removed from the site.

\section{Soil samples}

Phytophthora kernoviae was obtained from at least one of the four plots during the months of April to November inclusive, and from all four plots in July (mid-winter). Phytophthora kernoviae was not recovered during the months of December through March (summer). Plot results are given in Table 3.

\section{Understorey plants}

The most commonly occurring understorey plants throughout the forest are ferns, tree ferns and fern allies. Other understorey plants comprised both exotic and indigenous shrubs and ground cover plants. In total, 170 pieces of foliage from the seven most common understorey species were plated but no $P$. kernoviae was recovered.

\section{Inoculations}

\section{Stem inoculations}

Eight weeks after the plants were inoculated, two of the five Nothofagus truncata inoculated with NZFS 3062, two inoculated with NZFS 2646 and one of the five control plants had wilted and exhibited signs of root disease. These five plants were harvested at this time, 4 weeks before all other plants. Roots and soil of these N. truncata were tested for Phytophthora species, and Phytophthora cinnamomi Rands was recovered from both soil and roots of three plants. Phytophthora cinnamomi was considered likely to be the cause of the wilt of these three plants as no other plants had any indication of root disease. Although stem lesions had not formed at the inoculation point, $P$. kernoviae was recovered from the stem of two of the plants inoculated with NZFS 3062. Data from all plants was included in the analysis.

There had been little indication of ill-health in the foliage of any of the indigenous species (including the

Table 3 Recovery of Phytophthora kernoviae from soil samples collected monthly

\begin{tabular}{lllllllllllll}
\hline Plot & Apr & May & Jun & July & Aug & Sep & Oct & Nov & Dec & Jan & Feb & Mar \\
\hline $\mathrm{a}$ & + & + & + & + & + & + & - & + & - & - & - & - \\
$\mathrm{b}$ & + & + & + & + & + & + & + & - & - & - & - & - \\
$\mathrm{c}$ & - & - & + & + & - & - & - & - & - & - & - & - \\
$\mathrm{d}$ & - & - & - & + & - & - & + & - & - & - & - & - \\
\hline
\end{tabular}

remaining $N$. truncata plants) at 3 months when all other plants were harvested for stem dissection. Of all the exotic plants inoculated, only one of the nine $A n$. cherimola showed signs of wilt at this time.

Destructive sampling showed that there was no stem lesion development on any replicates of either Fuchsia excorticata, or Cordyline australis (Fig. 1). There was considerable variation in the number of replicates developing lesions for the other 14 native species, however. A visible lesion formed in only one of the 10 inoculated plants of each of the following species: Coprosma sp., Dacrycarpus dacrydioides, Dodonaea viscosa, Pseudowintera colorata, Pittosporum eugenioides, Nothofagus menziesii; and two of the Beilschmiedia tawa, Lep. scoparium and Pittosporum ralphii. Of the exotic species, the nine An. cherimola, eight of ten F. sylvatica plants and two of four $R$. catawbiense had a stem lesion. Indigenous hosts were more susceptible to stem lesion formation when inoculated with isolate NZFS 2646 (obtained from An. cherimola) than to NZFS 3062 (ex $R$. catawbiense) whereas the exotic F. sylvatica and An. cherimola were similarly susceptible to both isolates. Rhododendron catawbiense was only tested with NZFS 3062, and half of the plants developed lesions.

Mean lesion lengths (excluding the original wound length of $10 \mathrm{~mm}$ ) are shown in Fig. 2. Results for the two $P$. kernoviae isolates have been combined for the figure. The longest lesion, $270 \mathrm{~mm}$, was formed on one of the An. cherimola specimens, and the longest lesion on a native plant occurred on Myrsine australis with a lesion length of $80 \mathrm{~mm}$. The wilting $A n$. cherimola had been girdled at the inoculation point, and the lesion length was $40 \mathrm{~mm}$ (Fig. 2). All wounds on the control plants of every host species had healed, and there was no discolouration in the stem.

Recovery of $P$. kernoviae was more consistent from the exotic species than any of the indigenous hosts. Of the latter, $P$. kernoviae was not recovered from any plants of Melicytus ramiflorus, N. menziesii, Pit. eugenioides, Agathis australis, Myr. australis, Cordyline australis or Coprosma sp. but at varying rates from the other hosts (Fig. 3). Phytophthora kernoviae was occasionally recovered from Fch. excorticata, Pit. ralphii and Ps. colorata although lesions did not form. Phytophthora kernoviae was not recovered from any of the control plants.

\section{Foliage inoculation 1}

Symptom development Leaf-tip necrosis of leaves following dipping into a zoospore suspension was not common on the indigenous hosts. Where necrosis was recorded, it occurred only in low proportions, i.e. $B$. tawa (2\%), Fch. excorticata (4\%), Corynocarpus laevigatus (7 \%), D. dacrydioides (8 \%) and Gaultheria depressa (10 \%). Symptoms were recorded on all three exotic 


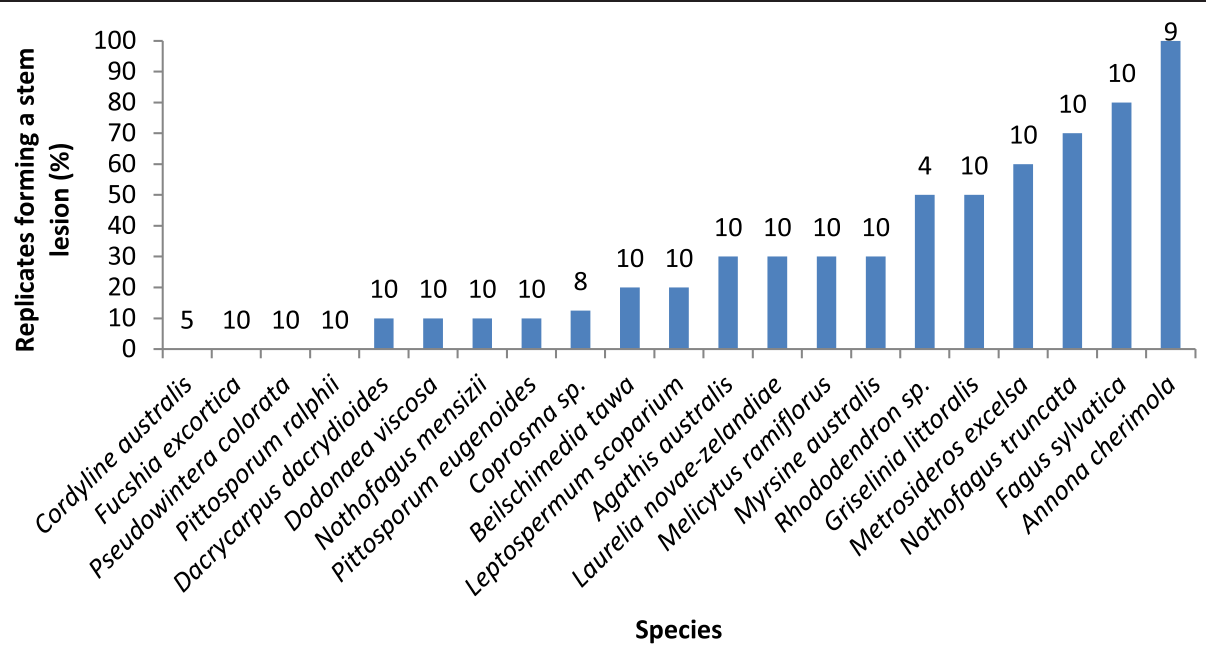

Fig. 1 Percentage of replicates within a species forming stem lesions. The number above the bar is the number of replicates of each host

species though percentages were also low with $F$. sylvatica (5\%), An. cherimola (15\%) and R. catawbiense (17\%). No lesions developed on any of the control treatments.

Pathogen recovery Although symptom development was uncommon, $P$. kernoviae was recovered from many of the asymptomatic leaves. Phytophthora kernoviae was recovered from leaves of 14 of the 27 native species tested though not from two of the species that exhibited symptoms (Cor. laevigatus and G. depressa). The proportion of pathogen recovery from leaves varied significantly among the tested species $\left(\chi^{2}=138.06, d f=31, P<0.0001\right)$. Recovery from foliage was highest for two of the exotic species, $R$. catawbiense $(56 \pm 26 \%)$ and F. sylvatica (42 \pm

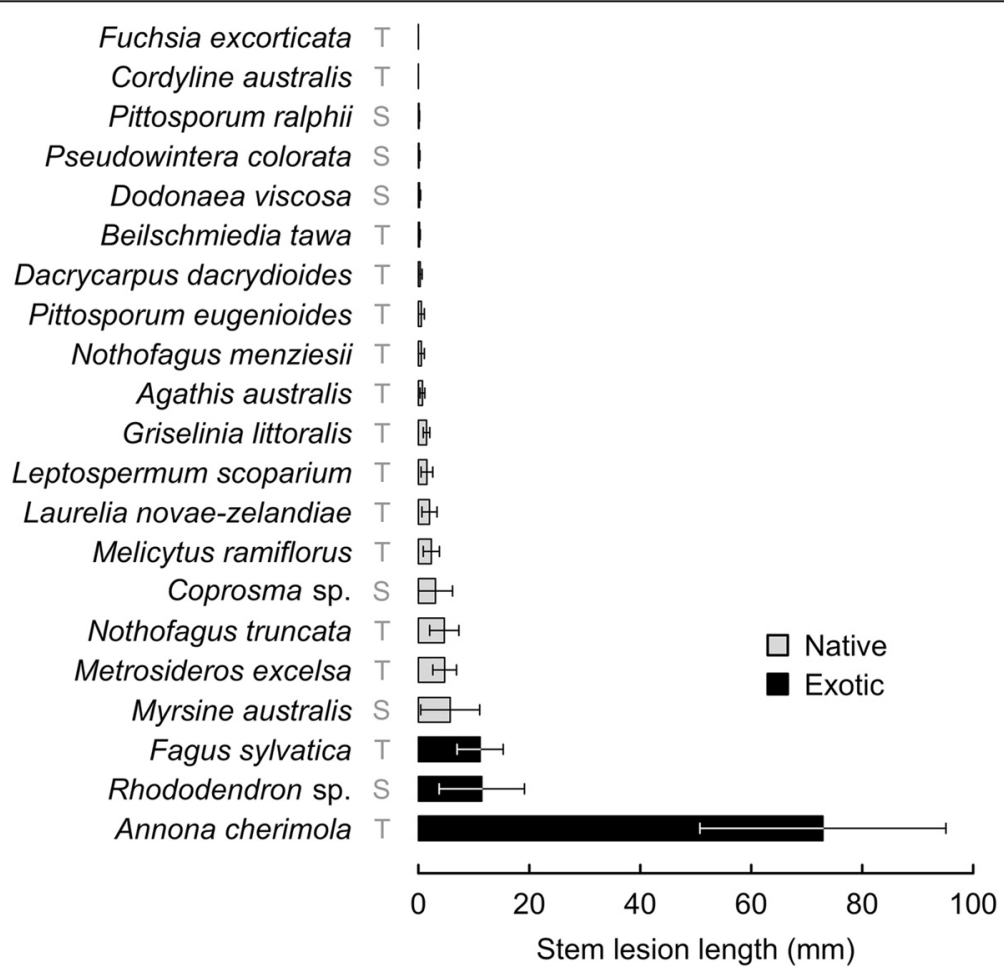

Fig. 2 Mean lengths of stem lesions induced by Phytophthora kernoviae. Means $\pm S E, n=2-9$. Key: $T=$ tree; and $S=$ shrub 


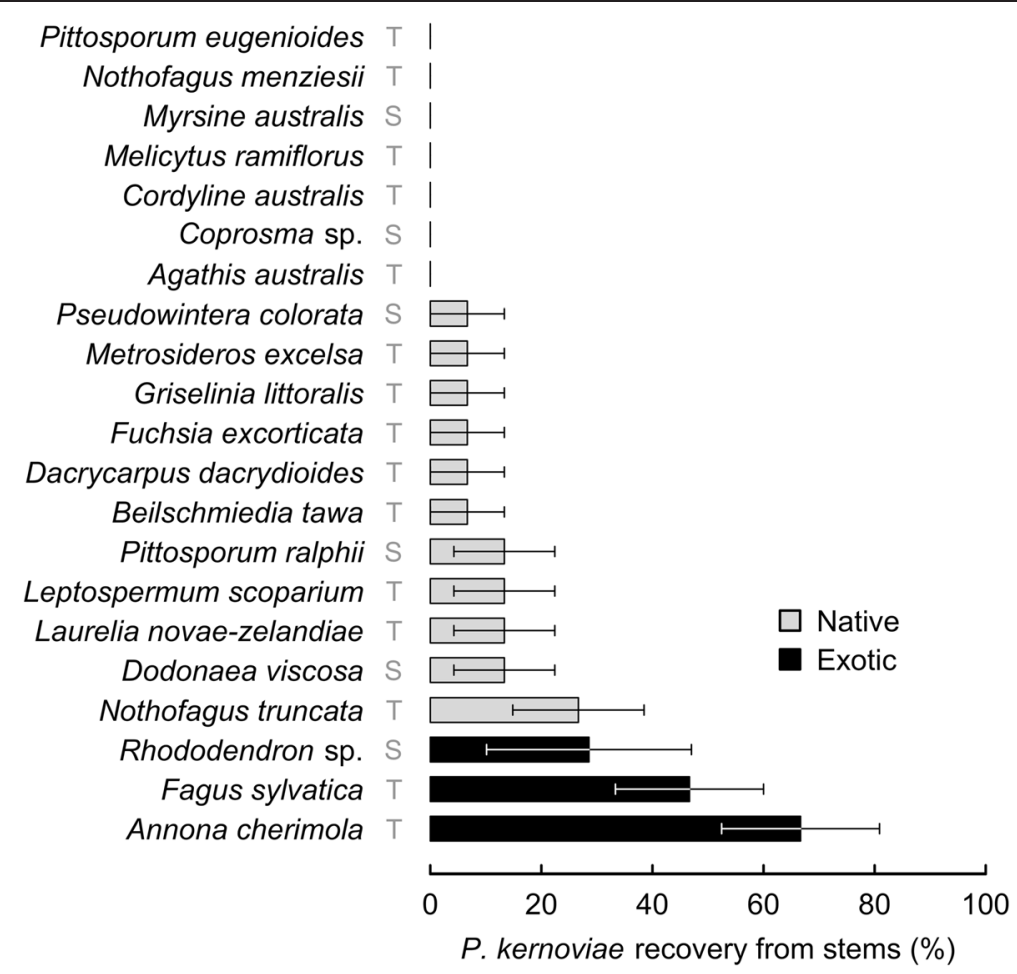

Fig. 3 Recovery of Phytophthora kernoviae from inoculated stems. Bars show the proportion of stems with pathogen recovery for each species (means $\pm S E, n=2-9$ ). Key: $T=$ tree; and $S=$ shrub

$15 \%)$, followed by the natives Fch. excorticata ( $25 \pm 12 \%)$ and Lep. scoparium $(20 \pm 20 \%)$. In all other species, less than $20 \%$ pathogen recovery was observed. Overall pathogen recovery was significantly higher in the exotic compared to the native taxa $\left(37 \pm 12.7 \%\right.$ vs. $5.6 \pm 1.4 \% ; \chi^{2}=$ 8.32, $d f=1, P=0.004)$. Among the five native fern species, $P$. kernoviae was recovered only from $\mathrm{Bl}$. novae-zelandiae fronds $(12 \pm 8 \%)$. Results are illustrated in Fig. 4 .

\section{Foliage inoculation 2}

Symptom development Complete results are given in Table 4. Lesions developed only on leaves (including both wounded and unwounded) of two of the three exotic species (An. cherimola and R. catawbiense). No lesions developed on leaves of any of the seven indigenous species tested.

Pathogen recovery Of the seven native plants tested, the pathogen was recovered from wounded but asymptomatic Bl. novae-zelandiae fronds (40 \%) and Loph. bullata leaves (10\%). Recovery rates from the exotics were variable with high recovery (corresponding to symptom formation) from both wounded + inoculated and unwounded + inoculated for rhododendron with similar recoveries from most of the asymptomatic F. sylvatica leaves. However, the pathogen was recovered from just one of the five wounded + inoculated $A n$. cherimola.

\section{Discussion}

The studies detailed here regarding the presence of $P$. kernoviae in the ecosystem, plus the tests on the susceptibility of New Zealand natives (through stem and foliar inoculations), have enhanced our knowledge of P. kernoviae occurrence and virulence in New Zealand.

Phytophthora kernoviae was recovered from the soil at the site from April to November but not during December to March (summer and early autumn) possibly because drier and warmer conditions during these seasons reduce activity of the oomycete. Webber (2008) reported that climatic analysis identified the western British Isles, with its mild temperatures and tendency to have high levels of precipitation, as suitable for establishment of $P$. kernoviae and very conducive for infection of aerial plant parts by the pathogen. Similar observations were made by Davidson et al. (2005) in their studies of Phytophthora ramorum Werres, De Cock and Man in't Veld (Brasier, Beales and S.A. Kirk), a species with comparable activity to P. kernoviae, in evergreen forests in California. Davidson et al. (2005) found that detectable levels of P. ramorum inoculum were present largely during the period of winter rains, detection ceased shortly after the rains stopped and did not occur during the hot, dry summer. The viability of 


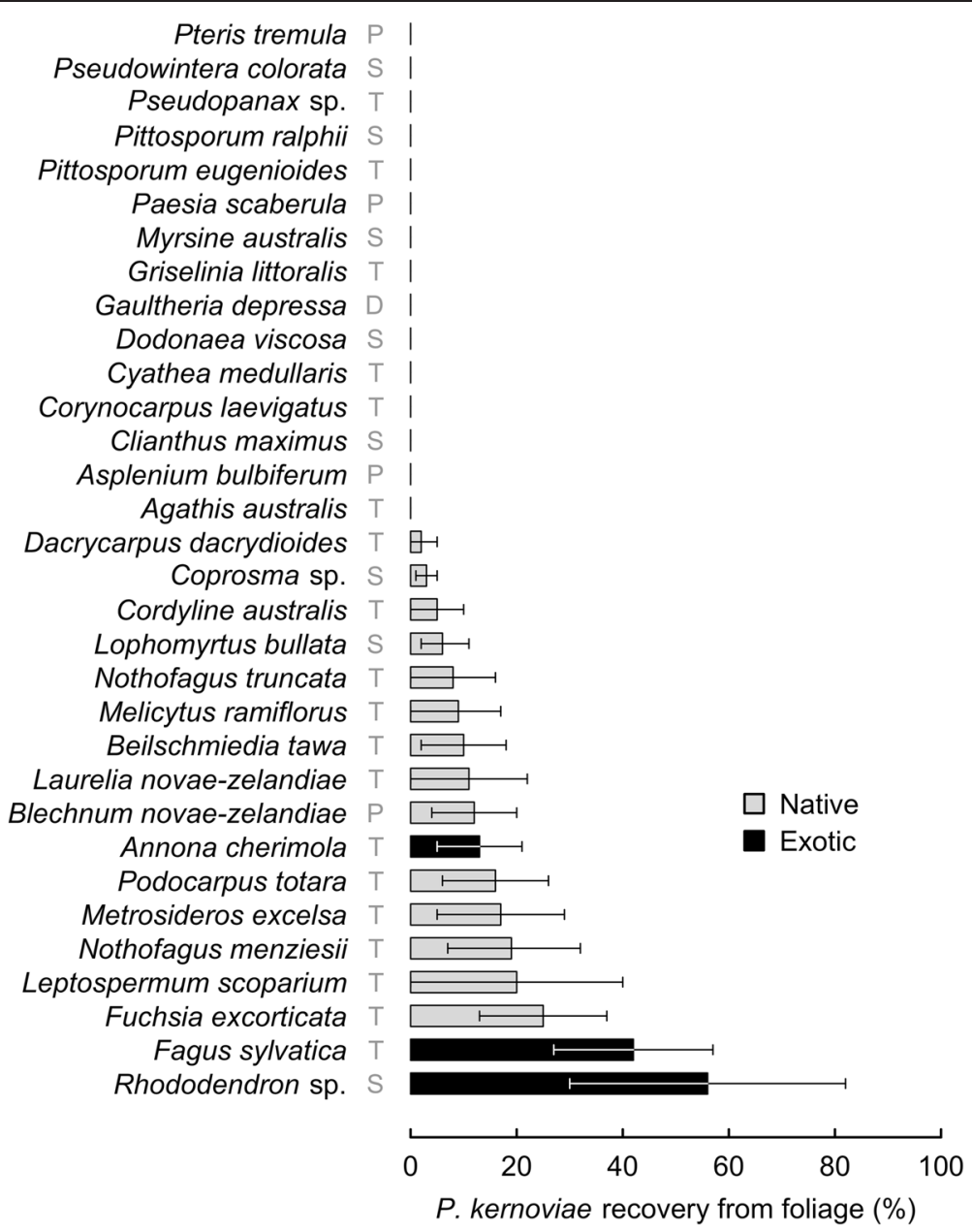

Fig. 4 Recovery of Phytophthora kernoviae from inoculated foliage for each woody species and four native fern species. Bars show the proportion of leaves with pathogen recovery per species (means $\pm S E, n=2-9$ ). Key: $T=$ tree; $S=$ shrub; $D=d$ warf shrub; and $P=$ non-woody perennial

propagules of $P$. kernoviae in the soil, especially dormant oospores, remains in question. We do not know as yet whether the soil is a reservoir of inactive inoculum during the summer/early autumn. Colonisation of root systems of plants by P. kernoviae has not been studied in New Zealand.

No foliar infection of understorey plants was identified in this study; therefore, the role of understorey plants in ensuring survival of the fungus over time at this site remains unknown. Brasier et al. (2005) reported that, in England, P. kernoviae is primarily a foliar pathogen and that its presence in soil was likely due to decay of fallen leaves from infected shrubs in the litter layer. In studies in the same part of south-west England, Webber (2009) found that $P$. kernoviae persisted in soil and litter for at least 3 years following removal of infected rhododendrons from the site. Fichtner et al. (2009, 2011) studied colonisation of roots of plants in woodland and heathlands in this area and found that P. kernoviae could be isolated from roots of asymptomatic Rhododendron ponticum L. plants and seedlings and from asymptomatic roots and rhizomes of heathland Vaccinium myrtillus L. Root infectivity and in planta oospore production suggest mechanisms of $P$. kernoviae survival.

Variable results were obtained from the Rhododendron indicator plants. The two plots where the plants were located were both under a high canopy of 20-year-old Pinus radiata but with differences in the surrounding understorey vegetation. Plot 'a' was adjacent to a large healthy camellia shrub that provided a partial barrier to needle drop from the Pinus radiata canopy and from other understorey vegetation (mainly ferns and small tree ferns). In contrast, plot 'b' was relatively open to the canopy and surrounded by ferns and ground-covering shrubs. The Pinus radiata canopy is a potential inoculum source given the subsequent finding (Dick et al. 2014) that Pinus radiata needles can be infected by 
Table 4 Foliage inoculation 2: Symptom expression and recovery of P. kernoviae (isolates NZFS 3062, 2646 and 3339)

\begin{tabular}{|c|c|c|c|c|c|c|c|c|c|}
\hline & \multicolumn{3}{|c|}{ No. leaves treated } & \multicolumn{3}{|c|}{ No. symptomatic leaves } & \multicolumn{3}{|c|}{ Pathogen recovery (no. of leaves) } \\
\hline & $\begin{array}{l}\text { Wounded } \\
\text { inoculated }\end{array}$ & $\begin{array}{l}\text { Unwounded } \\
\text { inoculated }\end{array}$ & $\begin{array}{l}\text { Wounded } \\
\text { control }\end{array}$ & $\begin{array}{l}\text { Wounded } \\
\text { inoculated }\end{array}$ & $\begin{array}{l}\text { Unwounded } \\
\text { inoculated }\end{array}$ & $\begin{array}{l}\text { Wounded } \\
\text { control }\end{array}$ & $\begin{array}{l}\text { Wounded } \\
\text { inoculated }\end{array}$ & $\begin{array}{l}\text { Unwounded } \\
\text { inoculated }\end{array}$ & $\begin{array}{l}\text { Wounded } \\
\text { control }\end{array}$ \\
\hline \multicolumn{10}{|l|}{ Native hosts } \\
\hline $\begin{array}{l}\text { Blechnum } \\
\text { novae-zelandiae }\end{array}$ & 5 & 5 & 5 & 0 & 0 & 0 & 2 & 0 & 0 \\
\hline $\begin{array}{l}\text { Beilschmiedia } \\
\text { tawa }\end{array}$ & 5 & 5 & 5 & 0 & 0 & 0 & 0 & 0 & 0 \\
\hline $\begin{array}{l}\text { Fuchsia } \\
\text { excorticata }\end{array}$ & 5 & 5 & 5 & 0 & 0 & 0 & 0 & 0 & 0 \\
\hline $\begin{array}{l}\text { Lophomyrtus } \\
\text { bullata }\end{array}$ & 10 & 10 & 5 & 0 & 0 & 0 & 1 & 0 & 0 \\
\hline $\begin{array}{l}\text { Metrosideros } \\
\text { excelsa }\end{array}$ & 5 & 5 & 5 & 0 & 0 & 0 & 0 & 0 & 0 \\
\hline $\begin{array}{l}\text { Podocarpus } \\
\text { totara }\end{array}$ & 20 & 20 & 5 & 0 & 0 & 0 & 0 & 0 & 0 \\
\hline $\begin{array}{l}\text { Pseudowintera } \\
\text { colorata }\end{array}$ & 5 & 5 & 5 & 0 & 0 & 0 & 0 & 0 & 0 \\
\hline \multicolumn{10}{|l|}{ Exotic hosts } \\
\hline $\begin{array}{l}\text { Annona } \\
\text { cherimola }\end{array}$ & 5 & 5 & 5 & 3 & 1 & 0 & 1 & 0 & 0 \\
\hline Fagus sylvatica & 5 & 5 & 5 & 0 & 0 & 0 & 4 & 3 & 0 \\
\hline $\begin{array}{l}\text { Rhododendron } \\
\text { catawbiense }\end{array}$ & 5 & 5 & 5 & 5 & 3 & 0 & 5 & 3 & 0 \\
\hline
\end{tabular}

Phytophthora kernoviae. Of the two planted rhododendrons, one (at plot 'a') remained asymptomatic whereas the other developed leaf lesions and branch tip dieback from which Phytophthora kernoviae was recovered. Likewise for the potted rhododendrons, there was neither symptom development nor recovery of Phytophthora kernoviae for any of the plants placed at plot 'a' but periodic results for plants from plot 'b'. As Phytophthora kernoviae recoveries from the soil were almost identical throughout the study at the two plots, and root infection was not recorded, the inoculum source would appear to be from other plants (albeit unidentified) either from the understorey or the canopy.

Susceptibility to Phytophthora kernoviae via stem inoculation was determined by lesion formation and also by recovery of the pathogen. The three exotic species inoculated via a wound on the lower stem all proved to be more susceptible than any of the indigenous species tested with the longest lesions recorded in An. cherimola stems. Widmer (2015) inoculated whole $A n$. cherimola plants by spraying with a zoospore suspension and then examining the non-wounded plants for stem and foliar lesions. No stem lesions were recorded by Widmer (2015) using this method. One isolate employed by Widmer (2015) (NZFS 2646) was also used in this study and when applied to a stem wound resulted in lesion formation of all the $A n$. cherimola and the death of one via girdling. An entry point to the stem would therefore appear to be a necessary precursor to stem invasion for this host. Foliage results for $A n$. cherimola were similar to those we recorded in this study ( $<20 \%$ symptom expression unless wounded) though Widmer (2015) also observed that he recorded significantly more leaf drop in inoculated as compared to non-inoculated plants. However in New Zealand, An. cherimola has been assumed to be highly susceptible to P. kernoviae in the wild. Phytophthora kernoviae was isolated from diseased plants obtained from two An. cherimola orchards in the far north of the country where there was extensive shoot and fruit blight, and branch cankering (Ramsfield et al. 2009). It is possible that additional adverse factors may also have contributed to the orchards becoming nonproductive.

A similar pattern of infection was recorded for the less susceptible $F$. sylvatica paralleling information from the United Kingdom where foliage infection is negligible (Denman et al. 2006b, Anon 2012), and primarily stem cankers are recorded on this host (Brasier et al. 2005, Brown and Brasier 2007). We did record, however, a high recovery rate of $P$. kernoviae from asymptomatic $F$. sylvatica foliage in our inoculation tests. Denman et al. (2009) postulated that asymptomatic infections may be quiescent, awaiting a change in host tissue that will trigger tissue colonisation and symptom expression. The 
relationship may also be dependent on inoculum density, with disease expression occurring at higher inoculum levels as suggested by Hansen et al. (2005) and Tooley et al. (2004) from their work on the similarly behaved $P$. ramorum.

Mean lesion length on $R$. catawbiense stems equalled that on F. sylvatica in this study but foliage was comparatively more susceptible with the highest percentage symptom development and recovery of $P$. kernoviae recorded for any host. Rhododendron species have frequently been recorded as susceptible hosts from the Northern hemisphere (Brasier et al. 2005; Anon 2012; Denman et al. 2009; Beales et al. 2006; Fichtner et al. 2012).

Rhododendron ponticum was considerably more susceptible to $P$. kernoviae than other hosts tested by Widmer (2015). Although there was no difference in stem lesion rating between the United Kingdom isolates, the isolate from the republic of Ireland scored significantly lower. In contrast, the six isolates from New Zealand were very variable; two with comparable virulence to the United Kingdom isolates and the others significantly lower. At our study site, little disease developed on the $R$. catawbiense indicator plants suggesting that the resident $P$. kernoviae population was of low virulence to this host.

Phytophthora kernoviae was recovered from a high proportion of symptomatic tissue from both stem and foliar inoculations. Recovery rates were also high from asymptomatic tissue for some species, e.g. Fch. excorticata (34 \% recovery and $4 \%$ symptoms). In contrast, Myr. australis and A. australis formed lesions, but $P$. kernoviae was rarely recovered from the tissue. A few of the native plants tested (e.g. Ps. colorata, Pit. eugenoides, Pit. ralphii, C. australis, $D$. dacrydioides) showed little susceptibility to $P$. kernoviae, never forming lesions or persisting in asymptomatic tissues. In general, no marked susceptibility of the native plants was discovered. Some species could carry the oomycete asymptomatically in inoculated detached leaves, indicating an ability to survive attack from $P$. kernoviae without causing visible damage but whether these plants are a natural part of a P. kernoviae life cycle remains to be determined. Denman et al. (2009) demonstrated that this occurs for a number of understorey species in woodland in the Britain. In the current study, there was little indication that ferns could be a component in the life cycle of $P$. kernoviae. No symptoms were recorded on the fronds dipped into a zoospore suspension, and $P$. kernoviae was recovered only from $\mathrm{Bl}$. novae-zealandiae (15\%). Although $P$. kernoviae was not recovered from $B l$. novaezealandiae during the understorey plant testing component of this study, it has been recorded as a host (MA Dick, unpublished data) and the isolate obtained (NZFS 2707) was one of those used in these inoculation experiments.
In 2014, P. kernoviae was found causing leaf necrosis and defoliation of Drimys winteri J.R.Forst. and G.Forst. in Chile (Sanfuentes et al. 2014). Drimys winteri is a native of Chile and Argentina where it is a dominant tree in the coastal temperate rain forests. This host is also planted in other parts of the world and is common in southern England where it has also been reported (Anon 2012; Webber 2008) to be susceptible to P. kernoviae (foliar necrosis and dieback). The New Zealand genus Pseudowintera is a member of the same family (Winteraceae). One of the three New Zealand species, Ps. color$a t a$, is a common understorey plant in native forests and was tested in this study but showed very little response to inoculation. No symptoms were formed on either foliage or stems; P. kernoviae was not recovered from any of the leaves and from only one $(10 \%)$ of the inoculated stems.

Few gymnosperms have been found susceptible to $P$. kernoviae infection. The 2012 host list published by Department for Environment, Food and Rural Affairs (DEFRA) (Anon 2012) includes just two species: shoot tip wilt and foliar blight of Podocarpus salignus D.Don (Podocarpaceae) and leaf and stem necrosis of Sequoiadendron giganteum (Lindl.) J.Buchholz (Cupressaceae). Foliage of the New Zealand native Podocarpus totara (Podocarpaceae) was tested in this study without a positive result. However, subsequently in 2012, foliage death in the lower crowns of a group of the native Prumnopitys ferruginea (miro), also a member of the Podocarpaceae, in the lower North Island was reported (Dick et al. 2014) and Phytophthora kernoviae was consistently isolated from affected needles. Apart from this one collection, all disease records in New Zealand are of exotic plants. Prumnopitys ferruginea is found growing on both lowland terrain and on hill slopes throughout the country and is also common in urban areas. Considering the wide distribution of Phytophthora kernoviae in New Zealand, it is likely that this host and the pathogen cohabit at other locations. Reasons for the disease outbreak on this occasion are unknown.

Ramsfield et al. (2009) reviewed available records of Phytophthora kernoviae in New Zealand and overseas. They considered the possibility that $P$. kernoviae may be native to New Zealand based on its relatively widespread distribution, its presence in soil in native forests or recently converted native forests, and on genetic diversity in the New Zealand population based on a limited number of isolates. In Great Britain, P. kernoviae is recognised as a serious pathogen (e.g. Brasier et al. 2005; Brown and Brasier 2007; Webber 2008) with a wide, and increasing, host range of both trees and shrubs (e.g. Beales et al. 2009) whereas in New Zealand records of disease are few in spite of records dating back approximately 60 years (Ramsfield et al. 2009). 
Phytophthora kernoviae is currently known only from the United Kingdom, the Republic of Ireland, Chile and New Zealand. Studies on P. kernoviae populations in Great Britain have shown considerable genetic uniformity. This, together with an initially limited geographic distribution, is consistent with a likely recent introduction (Brasier 2008). Concern about the potential spread to other countries has led to a number of studies examining potential host range (Fichtner et al. 2012; Widmer 2015). A range of isolates has been employed as information on differences in virulence between isolates helps to guide choices for regulatory agencies and researchers involved in monitoring programmes and for the conduct of host range tests. Hence Widmer (2015) compared the virulence of isolates of P. kernoviae from Great Britain and the Republic of Ireland with that of isolates from New Zealand. Leaf necrosis symptoms varied between isolates, but when results were combined within the geographical regions the isolates from the northern hemisphere resulted in a significantly higher percentage of necrosis than those from New Zealand.

The difference in disease expression between naturally infected vegetation in New Zealand and the northern hemisphere is striking. There is very little genetic variation in the population from Great Britain whereas population genetic studies have shown considerable variability exists within the New Zealand population (D. Cooke, D. Studholme and R. McDougal, unpublished data). Results from the inoculation study carried out by Widmer (2015) support these observations.

The goal of the studies reported in this paper was to gather further knowledge on interactions between Phytophthora kernoviae and native plants and environments. No evidence of disease of native plants was found in this study and there is only one record of a natural disease caused by Phytophthora kernoviae to a native host, that of Prumnopitys ferruginea in 2012.

\section{Conclusions}

Based on the results of the inoculations and the lack of historical records of disease of indigenous plants associated with P. kernoviae, this oomycete does not appear to be a damaging pathogen of New Zealand's indigenous flora. This may indicate that it has co-evolved with the flora. The recent finding of P. kernoviae in Chile associated with lesions on fallen leaves of $D$. winteri (Sanfuentes et al. 2014) may indicate a Gondwanan connection.

To gain a better understanding of the role of $P$. kernoviae in New Zealand ecosystems, further investigations need to be carried out. These include expanding host inoculation tests with a wider range of isolates, examining the ability of indigenous flora to support sporulation on asymptomatic foliage, and survival of P. kernoviae in roots and soil. The results from these preliminary studies suggest that exotic plant species are more likely to be potential susceptible hosts than indigenous species. New Zealand depends heavily on exotic plants to support its infrastructure and it is therefore encouraging that so few disease records have emerged in the past $60+$ years.

\section{Competing interests}

The authors declare that they have no competing interests.

\section{Authors' contributions}

Field and laboratory work was carried out by JG and MD. MB carried out the statistical analysis. All authors read and approved the final manuscript.

\section{Acknowledgements}

Rita Tetenburg and Pam Smith are thanked for their technical assistance. We are also grateful to Peter Gadgil and Rebecca McDougal for discussion and advice on the manuscript. Funding was provided by the New Zealand Forest Owners' Association and the New Zealand Ministry for Primary Industries.

Received: 6 May 2015 Accepted: 29 September 2015

Published online: 12 November 2015

\section{References}

Anon (2012). Fera list of natural hosts of Phytophthora kernoviae with symptom and location. Resource document. The Food and Environment Research Agency. http://webarchive.nationalarchives.gov.uk/20140904082245/http:// www.fera.defra.gov.uk/plants/plantHealth/pestsDiseases/phytophthora/ documents/pK. Accessed 13 October 2015.

Beales, PA, Lane, CR, Barton, VC, \& Giltrap, PG. (2006). Phytophthora kernoviae on ornamentals in the UK. EPPO Bulletin, 36(2), 377-379.

Beales, PA, Giltrap, PG, Payne, A, \& Ingram, N. (2009). A new threat to UK heathland from Phytophthora kernoviae on Vaccinium myrtillus in the wild. Plant Pathology, 58(2), 393.

Brasier, C. (2008). Phytophthora ramorum + P. kernoviae = international biosecurity failure. In Frankel, SJ, Kliejunas, JT, \& Palmieri, KM. (Tech. Coords.). Proceedings of the Sudden Oak Death Third Science Symposium, March 5-9, 2007, Santa Rosa, California. (USDA Forest Service General Technical Report PSW-GTR-214, pp. 133-139). Albany, CA, USA: US Department of Agriculture, Forest Service, Pacific Southwest Research Station

Brasier, CM, Beales, PA, Kirk, SA, Denman, S, \& Rose, J. (2005). Phytophthora kernoviae sp. nov., an invasive pathogen causing bleeding stem lesions on forest trees and foliar necrosis of ornamentals in the UK. Mycological Research, 109(8), 853-859.

Brown, AV, \& Brasier, CM. (2007). Colonization of tree xylem by Phytophthora ramorum, P. kernoviae and other Phytophthora species. Plant Pathology, 56(2), 227-241

Davidson, JM, Wickland, AC, Patterson, HA, Falk, KR, \& Rizzo, DM. (2005). Transmission of Phytophthora ramorum in mixed evergreen forest in California. Phytopathology, 95(5), 587-596.

Denman, S, Kirk, SA, Brasier, CM, \& Webber, JF. (2005). In vitro leaf inoculation studies as an indication of tree foliage susceptibility to Phytophthora ramorum in the UK. Plant Pathology, 54(4), 512-521.

Denman, S, Kirk, S, Whybrow, A, Orton, E, \& Webber, JF. (2006a). Phytophthora kernoviae and $P$. ramorum: host susceptibility and sporulation potential on foliage of susceptible trees. EPPO Bulletin, 36(2), 373-376. doi:10.1111/ j.1365-2338.2006.01014.

Denman, S, Brasier, CM, Brown, A, Kirk, SA, Orton, E, Webber JF. (2006b). Preliminary results of foliage susceptibility to Phytophthora kernoviae sp. nov.: a new pathogen of forest trees in the UK. [Poster]. Presented at the Third International IUFRO working party S07.02.09. Freisling, Germany, 11-18 September 2004.

Denman, S, Kirk, SA, Moralejo, E, \& Webber, JF. (2009). Phytophthora ramorum and Phytophthora kernoviae on naturally infected asymptomatic foliage. EPPO Bulletin, 39(1), 105-111. doi:10.1111/j.1365-2338.2009.02243.x.

Dick, MA, Williams, NM, Bader, MK, Gardner, JF, \& Bulman, LS. (2014). Pathogenicity of Phytophthora pluvialis to Pinus radiata and its relation with red needle cast disease in New Zealand. New Zealand Journal of Forestry Science, 44, 6. doi:10.1186/s40490-014-0006-7. 
Erwin, DC, \& Robeiro, O. (1996). Phytophthora diseases worldwide. St Paul, MN, USA: APS Press.

Fichtner, EJ, Rizzo, DM, Kirk, S, \& Webber, J. (2009). Epidemiology of Phytophthora kernoviae in UK woodlands and heathland and risk to North American forests. (Abstr.) Phytopathology, 99, S35.

Fichtner, EJ, Rizzo, DM, Kirk, S, \& Webber, J. (2011). Root infections may challenge management of invasive Phytophthora spp. in U.K. woodlands. Plant Disease, 95, 13-18.

Fichtner, EJ, Rizzo, DM, Kirk, SA, \& Webber, JF. (2012). Infectivity and sporulation potential of Phytophthora kernoviae to select North American native plants. Plant Pathology, 61(2), 224-233.

Hansen, EM, Parke, JL, \& Sutton, W. (2005). Susceptibility of Oregon forest trees and shrubs to Phytophthora ramorum: a comparison of artificial inoculation and natural infection. Plant Disease, 89(1), 63-70

Jeffers, SN, \& Martin, SB. (1986). Comparison of two media selective for Phytophthora and Pythium species. Plant Disease, 70(11), 1038-1043.

Kosmidis, I. (2013). brglm: Bias reduction in binomial-response Generalized Linear Models. R package version, 0, 5-9. http://www.ucl.ac.uk/ ucakiko/ software.htm

McAlonan, MJ. (1970). An undescribed Phytophthora sp. recovered from beneath stands of Pinus radiata (p. 64). New Zealand: Master of Science Thesis, Auckland University.

Pinheiro, J, Bates, D, DebRoy, S, Sarkar, D, \& Core Team, R. (2014). nlme: Linear and Nonlinear Mixed Effects Models. R package version, 3, 1-117.

R Core Team. (2014). R: A language and environment for statistical computing R Foundation for Statistical Computing, Vienna, Austria. URL http://www.Rproject.org/

Ramsfield, T, Dick, MA, Beever, RE, Horner, IJ, McAlonan, MJ, \& Hill, CF. (2009). In Phytophthora kernoviae in New Zealand. Phytophthora in forests and natural ecosystems (pp. 47-53). Monterey, California: Proceedings of the Fourth Meeting of IUFRO Working Party 507.02.09. August 26-31, 2007.

Rigby, RA, \& Stasinopoulos, DM. (2005). Generalized additive models for location, scale and shape. Applied Statistics, 54(3), 507-554.

Sanfuentes, E, Fajardo, S, Sabag, M, Hansen, E, González, M. (2014) Phytophthora kernoviae detection in Drimys winteri (Winter's Bark) forest of southern Chile. Programme Abstracts of the Seventh meeting of IUFRO Working Party, 7.02.09, (p 45). November 10-14, 2014, Patagonia, Argentina. http://www.iufrophytophthora2014.org/downloads/ proceedings.pdf

Tooley, PW, Kyde, KL, \& Englander, L. (2004). Susceptibility of select ericaceous ornamental host species to Phytophthora ramorum. Plant Disease, 88(9), 993-999.

Webber, JF (2008). Status of Phytophthora ramorum and P. kernoviae in Europe. In Frankel, SJ, Kliejunas, JT \& Palmieri, KM. (Tech. Coords.). In Proceedings of the Sudden Oak Death Third Science Symposium, March 5-9, 2007, Santa Rosa, California. (USDA Forest Service General Technical Report PSW-GTR-214, pp. 19-26). Albany, CA, USA: US Department of Agriculture, Forest Service, Pacific Southwest Research Station.

Webber, JF (2009). Management of Phytophthora kernoviae and P. ramorum in Southwest England. In Goheen, EM \& Frankel, SJ (Tech. Coords.). Phytophthoras in Forests and Natural Ecosystems. Proceedings of the Fourth Meeting of the International Union of Forest Research Organizations (IUFRO) Working Party 07.02.09. August 26-31, 2007, Monterey, California. (USDA Forest Service General Technical Report PSW-GTR-221, pp. 177-183). Albany, CA, USA: US Department of Agriculture, Forest Service, Pacific Southwest Research Station.

Widmer, TL. (2015). Differences in sporulation and virulence of Phytophthora kernoviae isolates originating from two distinct geographical regions. Plant Disease, 99(4), 460-466.

Submit your manuscript to a SpringerOpen ${ }^{\odot}$ journal and benefit from:

- Convenient online submission

- Rigorous peer review

- Immediate publication on acceptance

- Open access: articles freely available online

- High visibility within the field

- Retaining the copyright to your article

Submit your next manuscript at $>$ springeropen.com 